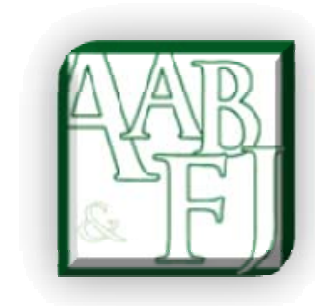

\title{
Director Remuneration Pay: Trends During and After the Financial Crisis of 2007 to 2009
}

Syaiful Baharee Jaafar ${ }^{1}$ and Kieran James ${ }^{2}$

\begin{abstract}
The objective of this study is to examine the trends of director remuneration in Malaysia's publicly listed companies. The proxies for executive pay are based on cash remuneration consisting of fees, salary, bonuses, and benefits to kin. Based on the data collected from 486 publicly listed companies in Bursa Malaysia from 2007 to 2009, we empirically tested findings that the trends for remuneration increased during and after the financial crisis. The study also reveals that the structure of remuneration, such as salary and bonuses for executives, showed an increasing trend during and after the financial crisis; however, it shows that the trend of director remuneration in family firms after the financial crisis was decreasing. Further analysis indicates that family members were willing to accept lower fees, bonuses, and benefits to kin in order to maintain cash flow. Our study suggests that no expropriation existed in family firms during and after the financial crisis. However, executives in non-family firms are less interested in accepting lower remuneration as part of a contract.
\end{abstract}

JEL Classification: G30, G32 and G34

\footnotetext{
${ }^{1}$ Polytechnic Tuanku Sultanah Bahiyah, Malaysia (Corresponding author: syaiful_1974@yahoo.com.my)

${ }^{2}$ University of Fiji, Fiji (kieran_james@yahoo.com)
} 


\section{Introduction}

The situation was different in 2007 and 2008, when the financial crisis that occurred in the U.S. and other Western economies did not negatively affect developing countries, including Malaysia. This is probably because the developing countries had good growth and policies, having learned lessons from the 1997-1998 financial crisis (Naudé, 2009). In Malaysia, the Malaysia Code of Corporate Governance (MCCG), established in 2000 and revised in 2007, introduced regulations for corporate governance best practices for listed companies. Naudè (2009, p. 9) explains that developing countries' banks were not directly negatively impacted. Most banks in developing countries were only marginally exposed to the US subprime crisis, so that a direct impact on their banking systems was largely avoided.

With regard to the 1997-1998 financial crisis, the MCCG was launched in 2000. The code provides improved insight for better achievement for publicly listed companies. Therefore, components of corporate governance, such as composition of board of directors, audit committee, and remuneration, became subjects for many scholars (Christopher, Hassan, \& Street, 2005; Durisin \& Puzone, 2009; Filatotchev, 2009). Demb and Neubauer (1992) explain the framework of corporate governance as responsible for firm performance. Its components need to be integrated and matched with firms' strategies for enhancing performance. For example, the components board structure, board composition, board size (Jensen, 1993) and meetings must be reviewed and effectiveness established during implementation. Similarly, the remuneration structure involving a remuneration committee (Salim \& Wan-Hussin, 2009) the level of remuneration (Abdul Wahab \& Abdul Rahman 2009), and structure of the remuneration (Mehran, 1995) must be looked as a whole package, not as individual components. Such a holistic approach can positively improve governance practice.

Remuneration is provided to attract and retain executives and should reflect a board's responsibilities and expertise and the complexity of the company's activities. Furthermore, it should also be aligned with the business strategy and long-term objectives of the company. The level of remuneration should be maintained or increased; this drives executive motivation and ensures the survival of the firm. However, these remuneration policies and procedures are difficult to implement when the firm is affected by a crisis. A firm cannot borrow money from a financial institution when it is on the verge of bankruptcy. As a result, business is slowed and may not be able to expand in order to make loan payments to the creditor, and directors may be less motivated if their remuneration is cut off. According to Raviv and Landskroner (2010, p. 4), the first stage of the financial crisis was characterised by the bankruptcy of many financial institutions and the bailout of some others. The second stage was characterised by a freeze in lending to households and businesses.

Malaysia is one of the developing countries with a strong relationship with the United States and other Western countries in terms of export trading. The crisis that has hit these countries had implications for Malaysia's export earnings and is likely to lead to a substantial decline in export earnings in countries such as China, India, Japan, Korea, Malaysia, and others (Naudé, 2009, p. 5). The expected declines will come through a combination of declines in commodity prices and declines in demand for their goods from advanced economies.

A board of directors' remuneration is very important in ensuring that motivation remains

and better performance is achieved. However, increasing remuneration during that period shows that expropriation will occur and possibly impact firm operation.

This paper makes contribution to the existing literature on remuneration. Previous studies investigate the relationship between remuneration and performance (S. Basu, L.-S. Hwang, T. Mitsudome, \& J. Weintrop, 2007; Doucouliagos, Askary, \& Haman, 2007), 
determinant of remuneration (Gomez-Mejia, Larraza-Kintana, \& Makri, 2003), and institutional investor and remuneration moderated by political connection (Abdul Wahab \& Abdul Rahman, 2009). There have been fewer studies examining the trends of director remuneration after and during the financial crisis in 2007 and 2008 from the Malaysian perspective.

Motivating a board of directors to work hard may be a reason for higher remuneration. However, the trends of remuneration show that expropriation possibly occurs during a financial crisis in a family firm. The remuneration may be higher in family firms due to power and control in their hands. However, lower remuneration may be awarded to ensure cash flow remains for business emergencies.

The objective of this paper is to examine the trends of executive pay in Malaysian publicly listed companies during and after the financial crisis, from 2007 to 2009. This study finds evidence of a trend of increasing remuneration, during and after the financial crisis. Furthermore, evidence shows that salaries and bonuses increased during and after the financial crisis. However, this study shows a trend of decreasing director remuneration in family firms after the financial crisis. Further analysis indicates that family members were willing to accept lower fees, bonuses, and benefits to kin in order to maintain cash flow. Our study suggests that no expropriation took place in family firms during and after the financial crisis. However, executives in non-family firms were less interested in accepting lower remuneration as part of a contract.

The remaining chapters are organized as follows: Section 2 outlines our hypothesis while fully developing the ideas from past research that are most relevant to the present study. Research design and methodology issues are explored in section 3. Details of the final sample and measurement of variables are also discussed in this chapter. The results and discussion are presented in section 4. Section 5 sets out conclusions, limitations, and some suggestions for further research.

\section{Literature Review}

The literature generally suggests that better remuneration, designed by remuneration committees, may mitigate agency problems (Andreas, Rapp, \& Wolff, 2010; MC; Jensen \& Meckling, 1976) and achieve better performance (Bender, 2007; Cheng \& Firth, 2006; Kaplan, 1994; Murphy, 1985). Agency problems become serious when a board of directors wants to increase personal wealth but shareholders prefer to maximise profit (E. Fama \& Jensen, 1983; E. F. Fama, 1980; MC; Jensen \& Meckling, 1976). The conflict has attracted many researchers to look further and is mainly discussed in agency theory (Bebchuk \& Fried, 2003; Cheng \& Firth, 2006; E. Fama \& Jensen, 1983; MC; Jensen \& Meckling, 1976). These studies focus on remuneration that aligns the interests of a board of directors and shareholders in order to mitigate agency problems.

Agency theory is limited to explaining the conflict of interest between majority and minority shareholders in family firms. In family firms, there is no separation between ownership and management, or control (Anderson \& Reeb, 2003; Claessens, Djankov, \& Lang, 2000; Gomez-Mejia et al., 2003; La Porta, Lopez-de-Silanes, Shleifer, \& Vishny, 1999), which contrasts with non-family firms. Regardless, there is potential for increased conflict between majority and minority shareholders in family firms (Peng \& Jiang, 2010; Young, Peng, Ahlstrom, Bruton, \& Jiang, 2008). For example, the uniqueness of family firms is closely related to the fact that key positions within the firms are held by family members, who may even hold more than one important position simultaneously. As a result, this creates space for expropriation. 
Moreover, agency theory suggests that an optimal contract drives board of director motivation and a willingness to work toward shareholder interests if it is satisfied with the contract (Bebchuk \& Fried, 2003). Pay for performance may motivate a board to utilise skills, knowledge, and experience through better strategies and planning. As a result, business tends to expand via mergers or new branches or products. Doucouliagos et al. (2007) found no evidence that director remuneration is more sensitive to poor performance than to better performance.

MCCG (2007 revised, p. 7) explains:

Levels of remuneration should be sufficient to attract and retain the directors needed to run the company successfully. The component parts of remuneration should be structured so as to link rewards to corporate and individual performance, in the case of executive directors. In the case of non-executive directors, the level of remuneration should reflect the experience and level of responsibilities undertaken by the particular non-executive concerned.

The structure of remuneration, such as fees, salary, bonuses, and benefits to kin must be taken into account in a remuneration setting because it has implications for director motivation. This motivation may drive directors to be creative, with good ideas for maintaining the success of the firm through enhanced performance. Previous studies have emphasised the significance of the structure of remuneration and motivation (Carter \& Zamora, 2007; Gallagher, Smith, \& Swan, 2006). For example, Carter and Zamora (2007) indicate that providing a suitable salary as remuneration can significantly influence the motivation of shareholders to increase a firm's performance. Gallagher et al. (2006) showed that providing higher salary is related to higher risk for executives. This drives higher motivation among executives to avoid risk and enhances better performance. With regard to family firms, Schulze et al. (2001) noted that family members are not interested in having long-term incentives, such as stock options, as part of their remuneration.

Cash remuneration in the form of salaries and bonuses is important because of its close relationship to wealth status. This is because it is linked to one's reputation in society as a respected person. Attainment of such status motivates executives to work harder to apply their expertise and experience. Croci et al. (2010) noted that remuneration is positively related to CEO level of experience. As a result, executives propose good strategies and planning that lead to long-term success. There are several reasons a board of directors will be interested in accepting a cash package. Firstly, it is linked to wealth status, whereby a director will have the ability to obtain a new car and house, travel around the world, become a member of a golf club, and take meals in exclusive places. This salary and bonus or fees are directly transferred to a bank account and can be used immediately. Secondly, the probability of keeping societal status relates to a better reputation and more respect.

Cash remuneration has become a subject of research by many researchers. For example, Cheung et al. (2005) studied the relationship between ownership concentration and executive compensation in Hong Kong, using proxies for executive remuneration by cash emoluments (salary, bonus, housing allowance, and other benefits). Leone et al. (2006) used cash remuneration (salary plus bonus) as a proxy in their study. Bushman and Smith (2001) found that accounting based earning closely associated with executives ' cash remuneration. Dong and Ozkan (2008) found that 70\% of CEO compensation in UK companies consists of cash pay (cash and annual bonus). This shows that the structure of remuneration is important for better performance. 
Remuneration procedures and policies can change when business is affected, for example, by a financial crisis. This crisis may have an impact on remuneration structure and influence the motivation of a board of directors in order to enhance performance. Attracting and retaining minority shareholder interest in investing in firms may depend on the ability of firms to build confidence in shareholders that they are capable of such long-term profitability.

Executives and non-executives should cooperate with each other to bring about longterm success by producing better planning and strategies. Remuneration is awarded depending on each person's responsibilities. It is very important to link executive remuneration to knowledge, skills, experience, and performance. In addition, non-executive remuneration be awarded based on their monitoring role on executive links with firm policies and procedures. Therefore, any change in remuneration procedures and policies may influence executive and non-executive remuneration. Many researchers have tested hypotheses regarding level of remuneration (Abdul Wahab \& Abdul Rahman, 2009; S. Basu, L. Hwang, T. Mitsudome, \& J. Weintrop, 2007; Cheung et al., 2005; Croci et al., 2010).

The structure and level of remuneration is important in determining remuneration, which should align with business performance. It is important to test the level of remuneration for an executive with regard to his or her responsibility in bringing about the firm's mission, vision, and objectives in the future. Furthermore, it is important to look in depth at the structure of remuneration to ensure that the combination is able to drive the board's motivation in order to create wealth. Therefore, the trend of a change in remuneration, either in level or structure, may influence the focus of a firm's board of directors.

Prior studies focused more on the relationship of remuneration to other entities. For example, remuneration and performance (S Basu et al., 2007; Brick, Palmon, \& Wald, 2006; Conyon \& Peck, 1998; Doucouliagos et al., 2007), institutional investors and remuneration (Abdul Wahab \& Abdul Rahman, 2009; Dong \& Ozkan, 2008), remuneration and family firms (Cheng \& Firth, 2006; Gomez-Mejia et al., 2003), and remuneration committees and remuneration (Anderson \& Bizjak, 2003). However, fewer studies focus on trends of remuneration as affected by remuneration policies and procedures.

The financial crisis that hit the United States and Europe spread into the Asian region, including Malaysia. This crisis may have created financial problems that affected remuneration policies and procedures. Furthermore, it may have influenced board of director motivation to work harder to bring success to firms. For family firms, expropriation via excessive remuneration was possible. Thus, the following hypotheses:

H1: Remuneration was affected during and after the financial crisis in 2007 to 2009.

H1a: Remuneration to family firms was affected during and after the financial crisis in 2007 to 2009.

$H 1 b$ : Remuneration to non-family firms was affected during and after the financial crisis in 2007 to 2009.

\section{Research Methodology}

The data were extracted from Bursa Malaysia's website (www.bursamalaysia.com). Bursa Malaysia was formerly known as Kuala Lumpur Stock Exchange (KLSE). In 2004, KLSE was renamed 'Bursa Malaysia', which consists of 'Main Market' (Main Board and Second Board) and 'ACE Market' (effective starting 3 August 2009). This study did not sample companies listed on the MESDAQ (Malaysia Exchange of Securities Dealing and Automated Quotation), known as ACE Market, which includes companies operating in advanced electronics, information technology, telecommunications, automation manufacturing systems, biotechnology and genetic engineering, healthcare, advanced 
material, energy, and aerospace and other emerging technologies (Saleh, Rahman, \& Hassan, 2009) . Exclusion of the companies listed on the ACE Market was due to differences between ACE companies and Main Market companies regarding the criteria for paid-up capital. The minimum paid-up capital for ACE companies is RM2 million for technology and nontechnology companies with a maximum of RM20 million for technology incubator companies, which is less than the main market criteria for paid-up capital, which is between RM40 million and RM60 million (Bursa Malaysia) ${ }^{3}$.

Bursa Malaysia is an exchange holding company approved under Section 15 of the Capital Markets and Services Act 2007. It operates a fully integrated exchange, offering the complete range of exchange-related services including trading, clearing, settlement and depository services. Many companies are interested in listing on Bursa Malaysia because of its: a) simple and clear requirements for listings; b) effective cost listing destination; and c) transparent and fully automated marketplace. Data were obtained from companies' annual reports as listed on www.bursamalaysia.com. As of 31 December 2009, 844 companies were listed in 'Main Markets' on Bursa Malaysia. The sample size for this study is 486 companies from Main Markets for years 2007, 2008, and 2009.

Total cash-based director remuneration consists of executive and non-executive remuneration. The proxy for cash remuneration consists of fees, salary, bonuses and benefits to kin. These measures have been widely used in prior research (e.g. Abdul Wahab \& Abdul Rahman, 2009; S Basu et al., 2007; MC Jensen \& Murphy, 1990; Ozkan, 2007).

Director remuneration data were obtained from annual reports from Bursa Malaysia as the level of remuneration and structure of executive and non-executive cash remuneration. The annual report disclosure was in the form of salary, bonus, benefit to kin, and fees for each category for executive directors or non-executive directors. If the cash remuneration was disclosed as an aggregate, without segregating each component, the data were not used because of the difficulty of identifying the level of remuneration. Similarly, when the total remuneration did not fall within executive categories, the samples were not used because of the difficulty of identifying the total remuneration earned by family members or otherwise.

Next, annual reports that disclosed only cash remuneration and not equity-based remuneration, such as stock options, were excluded from this study because the data could not be obtained. In other words, it was required that the proxies be collected in the correct way in order to answer the research question.

This study focused on family ownership structure according to two criteria: the first criterion is based on the Claessens et al (2002) definition of family as related by blood or marriage and is consistent with others' conceptualisations of family ownership. This means that family ownership was measured as members of the board of directors (e.g., CEO, chairman, etc.) who were related by blood or marriage. Annual reports from Bursa Malaysia include disclosure of the relationships among executives under board member profiles, which allows for categorisation of directors as family members.

The second criterion for family ownership is that family members hold not less than $20 \%$ of the voting stock (La Porta et al. 1999). The equity fraction is calculated based on direct and indirect shareholdings of family members. Either one or both of these criteria need to be fulfilled to be selected as family ownership. Claessens et al. (2002, p. 2746) explain that "we do not consider ownership by individual family members to be separate, and we use total ownership by each family group-defined as a group of people related by blood or marriageas the unit of analysis.”

\footnotetext{
${ }^{3}$ (http://www.bursamalaysia.com/website/bm/resources/download/brochure_listing_bursa.pdf; 4 June 2012)
} 


\section{Results and Discussion}

Table 1 presents trends of remuneration from 2007 to 2009 and shows that director remuneration increased during the financial crisis.

Table 1: Trend of Remuneration

\begin{tabular}{lccc}
\hline & DIRREM (million) & EXECREM (million) & NEDREM (million) \\
\hline $\mathbf{2 0 0 7}$ & 2.091 & 1.847 & 0.243 \\
$\mathbf{2 0 0 8}$ & 2.167 & 1.903 & 0.264 \\
$\mathbf{2 0 0 9}$ & 2.294 & 2.006 & 0.287 \\
\hline & DIRREM (\%) & EXECREM (\%) & NEDREM (\%) \\
\hline $\mathbf{2 0 0 7 - 2 0 0 8}$ & 3.507 & 2.942 & 7.954 \\
$\mathbf{2 0 0 8 - 2 0 0 9}$ & 5.536 & 5.134 & 8.013 \\
$\mathbf{2 0 0 7 - 2 0 0 9}$ & 8.849 & 7.926 & 15.331 \\
\hline
\end{tabular}

The trend continues to increase even after the financial crisis. Both executive and nonexecutive remuneration increased, either during the financial crisis or after. Further analysis shows that the director remuneration increased approximately $9 \%$ over this period. Table 1 presents the trend of remuneration during the period from 2007 to 2009. Non-executive remuneration increased slightly over this period. Furthermore, director and executive remuneration increased during the financial crisis but increased further after the financial crisis. This study suggests that the firms were not affected because Malaysia had in place a good practice of corporate governance after the financial crises of 1997 and 1998 regarding the level or structure of director remuneration. Furthermore, the financial crisis that hit the United States and European countries affected banking only marginally but not the banking system (Naudé, 2009). Table 2 shows the trend of structure of executive remuneration.

Table 2: Components of Executive Remuneration

\begin{tabular}{lcccc}
\hline & FEES (million) & SALARY (million) & BONUS (million) & BENEFIT OF KIN (million) \\
\hline $\mathbf{2 0 0 7}$ & 0.087 & 1.338 & 0.189 & 0.232 \\
$\mathbf{2 0 0 8}$ & 0.093 & 1.372 & 0.246 & 0.191 \\
$\mathbf{2 0 0 9}$ & 0.091 & 1.497 & 0.257 & 0.160 \\
\hline & FEES (\%) & SALARY (\%) & BONUS (\%) & BENEFIT OF KIN (\%) \\
\hline $\mathbf{2 0 0 7 2 0 0 8}$ & 6.452 & 2.478 & 23.171 & -21.466 \\
$\mathbf{2 0 0 8 - 2 0 0 9}$ & -2.198 & 8.350 & 4.280 & -19.375 \\
$\mathbf{2 0 0 7 - 2 0 0 9}$ & 4.396 & 10.621 & 26.459 & -45.000 \\
\hline
\end{tabular}

During the financial crisis, fees, salary, and bonuses increased but benefits to kin decreased. Furthermore, the post-financial crisis trend showed small changes, such as fees being affected (dropped off). Table 2 presents trends of the components of executive remuneration during the period from 2007 to 2009. While salary and bonuses went up during the financial crisis, benefits to kin and fees remained flat. Salaries underwent extreme increases after the financial crisis compared to bonuses and fees, which increased only slightly. Our study suggests that executives who take full responsibility for a firm's success then leave demand higher salaries. Gallagher et al. (2006) indicate that higher salary reflects higher risk.

Furthermore, we suggest that the components of remuneration, such as salary and bonus, are allocated more often than benefits to kin because they reflect status in society. For example, through salary and bonus, the executive has the ability to buy a house in a 
prestigious area and an expensive car, take luxury holiday trips (e.g., stay in five-star hotel suites). However, benefits to kin decreased sharply. Fees and benefits to kin may have been reduced in order to maintain cash flow within the firm. Table 3 shows the trend of the structure of components of non-executive remuneration during the period from 2007 to 2009.

Table 3: Components of Non Executive Remuneration

\begin{tabular}{lcccc}
\hline & FEES (million) & SALARY (million) & BONUS (million) & BENEFIT OF KIN (million) \\
\hline $\mathbf{2 0 0 7}$ & 0.169 & 0.045 & 0.009 & 0.018 \\
$\mathbf{2 0 0 8}$ & 0.181 & 0.052 & 0.012 & 0.017 \\
$\mathbf{2 0 0 9}$ & 0.198 & 0.054 & 0.013 & 0.020 \\
\hline & FEES (\%) & SALARY (\%) & BONUS (\%) & BENEFIT OF KIN (\%) \\
\hline $\mathbf{2 0 0 7 - 2 0 0 8}$ & 6.630 & 13.462 & 25.000 & -5.882 \\
$\mathbf{2 0 0 8 - 2 0 0 9}$ & 8.586 & 3.704 & 7.692 & 15.000 \\
$\mathbf{2 0 0 7 - 2 0 0 9}$ & 14.646 & 16.667 & 30.769 & 10.000 \\
\hline
\end{tabular}

The results show that all components of non-executive remuneration, except benefits to kin, increased during and after the financial crisis. Furthermore, Table 3 shows that fees, salaries, and bonuses increased, in contrast to benefits to kin, which declined over the same period. Analysis indicates that the nature of firms is to motivate non-executives by providing higher fees commensurate with their responsibility. MCCG (2007 revised, p. 11) explains that, in the case of non-executive directors, the level of remuneration should reflect the experience and level of responsibility undertaken by the particular non-executive concerned. Table 4 presents a univariate analysis related to the trend of remuneration in family firms and non-family firms during the period from 2007 to 2009.

Table 4: Trend of Remuneration in Family Firms and Non-Family Firms

\begin{tabular}{|c|c|c|c|c|}
\hline & $\begin{array}{c}(n=243) \\
\text { Family Firm }=1 \\
\text { Mean ('000) }\end{array}$ & $\begin{array}{c}(n=243) \\
\begin{array}{c}\text { Non-Family Firm }=0 \\
\text { Mean ('000) }\end{array}\end{array}$ & $\begin{array}{c}t \text { - test } \\
p=\text { value }\end{array}$ & $\begin{array}{c}\text { Mann Whitney } \\
p \text {-value }\end{array}$ \\
\hline \multicolumn{5}{|l|}{2007} \\
\hline DIRREM & 2.213 & 1.969 & 0.518 & $0.003^{* *}$ \\
\hline EXECREM & 1.999 & 1.695 & 0.412 & $0.000 * *$ \\
\hline NEDREM & 0.213 & 0.273 & 0.078 & $0.000 * *$ \\
\hline \multicolumn{5}{|l|}{2008} \\
\hline DIRREM & 2.270 & 2.066 & 0.571 & $0.001 * *$ \\
\hline EXECREM & 2.033 & 1.775 & 0.466 & $0.000 * *$ \\
\hline NEDREM & 0.236 & 0.290 & 0.109 & $0.000 * *$ \\
\hline \multicolumn{5}{|l|}{2009} \\
\hline DIRREM & 2.258 & 2.328 & 0.867 & $0.003 * *$ \\
\hline EXECREM & 2.019 & 1.994 & 0.950 & $0.000 * *$ \\
\hline NEDREM & 0.239 & 0.334 & $0.008 * *$ & $0.000 * *$ \\
\hline
\end{tabular}

Note: ** denote significance at the $5 \%$ and $1 \%$ level respectively.

Table 4 shows that, during the financial crisis, remuneration for family firms was similar to that of non-family firms and increased. Table 4 shows that director and executive remuneration decreased slightly in family firms, and increased in non-family firms, after the financial crisis. This implies that family firms were not affected during the financial crisis because there was high demand from the U.S. and European countries for business trading. However, after the crisis, the demand from these countries declined, which affected the firms' performances. Therefore, further analysis suggests that the level of remuneration in family 
firms was indeed affected by the financial crisis. Our study suggests that family members were willing to accept reduced remuneration in order to ensure the firm's survival through strong financials (i.e. increased cash flow). The results also indicate that family members were less interested in expropriation via remuneration. This is related to their purpose for incorporating the business: its long-term success and their preference to hand it over to the next generation.

Furthermore, family members tended to keep the top position secure because, after a financial crisis, a business is not usually fully recovered and it is harder to enhance performance. Gomez-Mejia et al. (2003) noted that executives among family members should be willing to accept lower remuneration in return for their service than is stated in their contract. Past studies show that an inverse relationship between ownership and remuneration (Barontini, Bozzi, Sant'Anna, \& della Libertà, 2010; Cheung et al., 2005; Gomez-Mejia et al., 2003). Dogan and Smyth (2002) state that salaries and fees paid to all directors are lower in ownership concentration. Regarding non-family firms, the level of remuneration was not affected during and after the financial crisis. As shown in Table 5, director and executive remuneration in non-family firms increased sharply in the period after the financial crisis. Our study suggests that executives were paid higher remuneration for their responsibility, complexity, and abilities such as skills and experience, to maintain good performance.

Table 5: Executive Remuneration in Family and Non-Family Firms

\begin{tabular}{lcccc}
\hline & $\begin{array}{c}(\mathrm{n}=257) \\
\text { Family Firm }=1 \\
\text { Mean ('000) }\end{array}$ & $\begin{array}{c}(\mathrm{n}=280) \\
\text { Non-Family Firm }=0 \\
\text { Mean ('000) }\end{array}$ & $\begin{array}{c}\boldsymbol{t} \text { - test } \\
\boldsymbol{p}=\text { value }\end{array}$ & $\begin{array}{c}\text { Mann Whitney } \\
\boldsymbol{p} \text { - value }\end{array}$ \\
\hline $\mathbf{2 0 0 7}$ & & & & $0.000^{* *}$ \\
\hline EXECFEES & 0.110 & 0.064 & $0.008^{* *}$ & $0.000^{* *}$ \\
EXECSAL & 1.354 & 1.321 & 0.914 & $0.001^{* *}$ \\
EXECBON & 0.232 & 0.146 & 0.218 & 0.871 \\
EXECBEN & 0.302 & 0.162 & 0.392 & $0.000^{* *}$ \\
\hline 2008 & & & 0.170 & $0.000^{* *}$ \\
\hline EXECFEES & 0.107 & 0.079 & 0.939 & $0.001^{* *}$ \\
EXECSAL & 1.383 & 1.361 & 0.081 & 0.550 \\
EXECBON & 0.369 & 0.125 & 0.530 & $0.000^{* *}$ \\
EXECBEN & 0.173 & 0.209 & & $0.000^{* *}$ \\
\hline 2009 & & & 0.141 & $0.017^{* *}$ \\
\hline EXECFEES & 0.106 & 0.076 & 0.693 & 0.574 \\
EXECSAL & 1.425 & 1.568 & 0.214 & 0.980 \\
EXECBON & 0.328 & 0.188 & & \\
EXECBEN & 0.159 & 0.160 & & \\
\hline
\end{tabular}

Note: ${ }^{* *}$ denote significance at the $5 \%$ and $1 \%$ level respectively.

Further discussion, as shown in Table 5, shows the trend of the structure of executive remuneration in family firms. Fees and benefits to kin were decreased during and after the financial crisis, but bonuses were affected only after the financial crisis. Furthermore, our study suggests that family members were willing to accept lower fees and bonuses in order to maintain cash flow. As a result, firms would have the ability to recover from the financial crisis.

The components of remuneration for fees, salary and benefits to kin increased during the financial crisis; however, bonuses decreased. Further analysis shows that fees and benefits to kin ceased to be part of remuneration; this is in contrast with salary and bonus, which increased after the financial crisis. Analysis indicates that firms will award higher 
remuneration, especially salary and bonus, to executives because it is linked to responsibility for enhancing performance. Furthermore, they are not willing to accept lower remuneration even though fees and benefit of kin are decreased

Table 6: Non Executive Remuneration in Family and Non-Family Firm

\begin{tabular}{lcccc}
\hline & $\begin{array}{c}(\mathrm{n}=257) \\
\text { Family Firm }=1 \\
\text { Mean ('000) }\end{array}$ & $\begin{array}{c}(\mathrm{n}=280) \\
\text { Non-Family Firm }=0 \\
\text { Mean ('000) }\end{array}$ & $\begin{array}{c}\boldsymbol{t} \text { - test } \\
\boldsymbol{p}=\text { value }\end{array}$ & $\begin{array}{c}\text { Mann } \\
\text { Whitney } \\
\boldsymbol{p} \text { - value }\end{array}$ \\
\hline 2007 & & & & \\
\hline NEDFEES & 0.135 & 0.203 & $0.000^{* *}$ & $0.000^{* *}$ \\
NEDSAL & 0.048 & 0.042 & 0.719 & 0.792 \\
NEDBON & 0.007 & 0.011 & 0.511 & 0.413 \\
NEDBEN & 0.021 & 0.016 & 0.694 & 0.358 \\
\hline 2008 & & & & $0.000^{* *}$ \\
\hline NEDFEES & 0.149 & 0.203 & $0.000^{* *}$ & 0.707 \\
NEDSAL & 0.058 & 0.042 & 0.530 & 0.445 \\
NEDBON & 0.009 & 0.011 & 0.409 & 0.372 \\
NEDBEN & 0.019 & 0.016 & 0.709 & $0.000^{* *}$ \\
\hline 2009 & & & & 0.945 \\
\hline NEDFEES & 0.160 & 0.236 & $0.000^{* *}$ & 0.333 \\
NEDSAL & 0.052 & 0.056 & 0.308 & 0.124 \\
NEDBON & 0.009 & 0.018 & 0.516 & \\
NEDBEN & 0.017 & 0.023 & & \\
\hline
\end{tabular}

Note: ** denote significance at the $5 \%$ and $1 \%$ level respectively.

Results show that fees, salary, and bonus increased, but benefits to kin decreased, during the financial crisis. However, results indicate that fees increased post financial crisis compared to salary and benefits to kin. Furthermore, bonus pay to non-executives did not change either during or after the financial crisis. Our study suggests that family firms tend to reduce salary and benefits to kin because increasing cash flow to effect recovery of finances may be affected by a financial crisis.

Results show that during and after the financial crisis, fees, salary and bonus were not affected for non-executives in family firms. However, the opposite was true of benefits to kin, which were affected during the financial crisis. Further analysis indicates that firms increased non-executive pay in order to improve performance during the financial crisis. Another reason is that non-executives are required to monitor a board of directors in the period after the financial crisis to ensure shareholder investment. According to Beasley (1996), independent directors are ready to use their power to monitor a board of directors.

\section{Conclusion}

This study examines the trend of executive pay during and after the financial crisis in Malaysian publicly listed companies. The sample size of this study was 486 companies for the years 2007, 2008, and 2009 from Bursa Malaysia. Results indicate a trend of increasing level of remuneration during and after the financial crisis. As result, Malaysian publicly listed companies were less affected by the financial crisis because of better corporate governance. Furthermore, the structure of remuneration indicates that salary and bonus were affected after the financial crisis. Our study suggests that the structures of remuneration, such as salary and bonus, are allocated more than benefits to kin because they reflect one's status in society. 
The level of remuneration in family firms for directors and executives were affected in the period after the financial crisis. Results show that family members were willing to accept lower bonus and benefits to kin in order to maintain cash flow. Furthermore, our results suggest that family members were less interested in expropriation via remuneration than they were in keeping their position in the firm secure. However, executives in non-family firms were less interested in accepting lower remuneration as part of their contracts. Hence, the fees and benefits were reduced but salary and bonus increased. Our results suggest that pay for executives in non-family firms should be increased during and after a financial crisis because the firm is not affected, and because it tends to motivate executives to utilise their skills and experience to enhance performance.

This study focuses only on cash remuneration such as fees, salaries, bonuses and benefits to kin, which makes up only one type of level of remuneration. Results were generalised to cash-based remuneration analysis only, but analysis based solely on cash remuneration likely does not show the complete picture. However, this study could not take into account remuneration related to stock options because the data were not available from annual reports. This limits the scope of the study regarding director remuneration. Further study could be done to investigate the relationship between remuneration and culture. Such investigation could provide useful insight into the role of culture in remuneration trends.

\section{References}

Abdul Wahab, E \& Abdul Rahman, R 2009, 'Institutional investors and director remuneration: do political connections matter?', Corporate Governance and Firm Performance, vol. 139.

Anderson, R \& Bizjak, J 2003, 'An empirical examination of the role of the CEO and the compensation committee in structuring executive pay* 1', Journal of Banking \& Finance, vol. 27, no. 7, pp. 1323-1348. http://dx.doi.org/10.1016/S0378-4266(02)00259$\underline{5}$

Anderson, R \& Reeb, D 2003, 'Founding-family ownership and firm performance: Evidence from the S\&P 500', Journal of Finance, vol. 58, no. 3, pp. 1301-1328. http://dx.doi.org/10.1111/1540-6261.00567

Andreas, J, Rapp, M \& Wolff, M 2010, 'Determinants of Director Compensation in Two-Tier Systems: Evidence from German Panel Data', Social Science Research Network.

Barontini, R \& Bozzi, S, 2010, 'CEO Compensation and Performance in Family Firms', Social Science Research Network.

Basu, S, Hwang, L, Mitsudome, T \& Weintrop, J 2007, 'Corporate governance, top executive compensation and firm performance in Japan', Pacific-Basin Finance Journal, vol. 15, no. 1, pp. 56-79. http://dx.doi.org/10.1016/j.pacfin.2006.05.002

Beasley, M 1996, 'An empirical analysis of the relation between the board of director composition and financial statement fraud', Accounting Review, vol. 71, no. 4, pp. 443465.

Bebchuk, L \& Fried, J 2003, 'Executive compensation as an agency problem', Journal of Economic Perspectives, vol. 17, no. 3, pp. 71-92. http://dx.doi.org/10.1257/089533003769204362

Bender, R 2007, 'Onwards and Upwards: why companies change their executive remuneration schemes, and why this leads to increases in pay', Corporate Governance: An International Review, vol. 15, no. 5, pp. 709-723. 
Brick, I, Palmon, O \& Wald, J 2006, 'CEO compensation, director compensation, and firm performance: Evidence of cronyism?', Journal of Corporate Finance, vol. 12, no. 3, pp. 403-423. http://dx.doi.org/10.1016/j.jcorpfin.2005.08.005

Bushman, R \& Smith, A 2001, 'Financial accounting information and corporate governance* 1', Journal of Accounting and Economics, vol. 32, no. 1-3, pp. 237-333. http://dx.doi.org/10.1016/S0165-4101(01)00027-1

Carter, M, \& Zamora, V 2007, Shareholder remuneration votes and CEO compensation design', Social Science Research Network.

Cheng, S, \& Firth, M 2006, 'Family ownership, corporate governance, and top executive compensation', Managerial and Decision Economics, vol. 27, no. 7, pp. 549-561. http://dx.doi.org/10.1002/mde.1273

Cheung, Y, Stouraitis, A \& Wong, A 2005, 'Ownership concentration and executive compensation in closely held firms: Evidence from Hong Kong', Journal of Empirical Finance, vol. 12, no. 4, pp. 511-532. http://dx.doi.org/10.1016/j.jempfin.2004.10.001

Christopher, T, Hassan, S \& Street, P 2005, 'Culture and Corporate Governance Statement Disclosure', Edith Cowan University, Western Australia, Australia

Claessens, S, Djankov, S \& Lang, L 2000, 'The separation of ownership and control in East Asian Corporations* 1', Journal of Financial Economics, vol. 58, no. 1-2, pp. 81-112. http://dx.doi.org/10.1016/S0304-405X(00)00067-2

Croci, E, Gonenc, H, Ozkan, N \& Italy, M 2010, CEO Compensation, Family Control, and Institutional Investors in Continental Europe.Social Science Research Netwok.

Demb, A \& Neubauer, F 1992, 'The corporate board: Confronting the paradoxes', Long Range Planning, vol. 25, no. 3, pp.9-20. http://dx.doi.org/10.1016/0024-6301(92)90364-8

Dogan, E \& Smyth, R 2002, 'Board remuneration, company performance, and ownership concentration: Evidence from publicly listed Malaysian companies’, ASEAN Economic Bulletin, vol. 19, no. 3, pp. 319-347. http://dx.doi.org/10.1355/AE19-3F

Dong, M \& Ozkan, A 2008, 'Institutional investors and director pay: An empirical study of UK companies', Journal of Multinational Financial Management, vol. 18, no. 1, pp. 1629. http://dx.doi.org/10.1016/j.mulfin.2007.06.001

Doucouliagos, H, Askary, S \& Haman, J 2007, 'Directors' Remuneration and Performance in Australian Banking', Journal compilation, vol. 15, no. 6.

Durisin, B \& Puzone, F 2009, 'Maturation of Corporate Governance Research, 1993-2007: An Assessment', Corporate Governance: An International Review, vol. 17, no. 3, pp. 266-291.

Fama, E, \& Jensen, M 1983, 'Separation of ownership and control', The Journal of Law and Economics, vol. 26, no. 2, p. 301. http://dx.doi.org/10.1086/467037

Fama, EF 1980, 'Agency Problems and the Theory of the Firm', The Journal of Political Economy, pp. 288-307. http://dx.doi.org/10.1086/260866

Filatotchev, I 2009, 'Taking Stock of Corporate Governance Research While Looking to the Future', Corporate Governance: An International Review, vol. 17, no. 3, pp. 257-265.

Gallagher, D, Smith, G \& Swan, P 2006, 'Do institutional investor really monitor executive compensation', Social Science Research Network.

Gomez-Mejia, L, Larraza-Kintana, M \& Makri, M 2003, 'The determinants of executive compensation in family-controlled public corporations', The Academy of Management Journal, pp. 226-237. http://dx.doi.org/10.2307/30040616

Jaafar, SB, Abdul Wahab, EA \& James, K 2012, 'Director remuneration and performance in Malaysia family firms: an expropriation matter?' World Review of Business Research, vol. 2, no. 4, pp. 204-222. 
Jensen, M \& Meckling, W 1976, 'Theory of the firm: Managerial behavior, agency costs and ownership structure', Journal of Financial Economics, vol. 3, no. 4, pp. 305-360. http://dx.doi.org/10.1016/0304-405X(76)90026-X

Jensen, M \& Murphy, K 1990, 'Performance pay and top-management incentives', Journal of Political Economy, vol. 98, no. 2, pp. 225-264. http://dx.doi.org/10.1086/261677

Jensen, M 1993, 'The Modern industrial revolution,exit and the failure of internal control systems', The Journal of Finance, vol. 48, no.3, pp. 831-880. http://dx.doi.org/10.1111/j.1540-6261.1993.tb04022.x

Kaplan, S 1994, 'Top executives, turnover, and firm performance in Germany', Journal of Law, Economics, and Organization, vol. 10, no. 1, p. 142. http://dx.doi.org/10.1093/jleo/10.1.142

La Porta, R, Lopez-de-Silanes, F, Shleifer, A \& Vishny, R 1999, 'Corporate ownership around the world', Journal of Finance, vol. 54, no. 2, pp. 471-517. http://dx.doi.org/10.1111/0022-1082.00115

Leone, AJ, Wu, JS \& Zimmerman, JL 2006, 'Asymmetric sensitivity of CEO cash compensation to stock returns', Journal of Accounting and Economics, vol. 42, no. 1-2, pp. 167-192. http://dx.doi.org/10.1016/j.jacceco.2006.04.001

Malaysia Code of Corporate Governance, 2000, viewed 3 Mac 2012, <http:// www.ecgi.org/codes/documents/mccg_mar2000.pdf>

Malaysia Code of Corporate Governance Revised 2007, viewed 3 Mac 2012 <http://www.ecgi.org/codes/documents/cg_code_malaysia_2007_en.pdf>

Mehran, H 1995, 'Executive compensation structure, ownership, and firm performance', Journal of Financial Economics, vol. 38, no. 2, pp. 163-184. http://dx.doi.org/10.1016/0304-405X(94)00809-F

Murphy, K 1985, 'Corporate performance and managerial remuneration: An empirical analysis’, Journal of Accounting and Economics, vol. 7, no. 1-3, pp. 11-42. http://dx.doi.org/10.1016/0165-4101(85)90026-6

Murphy, KJ 1999, 'Executive compensation', Handbook of Labor Economics, vol. 3, pp. 2485-2563. http://dx.doi.org/10.1016/S1573-4463(99)30024-9

Naudé, WA \& Research, WIfDE 2009, 'The financial crisis of 2008 and the developing countries: United Nations University, World Institute for Development Economics Research', United Nations University.

Ozkan, N 2007, 'Do corporate governance mechanisms influence CEO compensation? An empirical investigation of UK companies', Journal of Multinational Financial Management, vol. 17, no. 5, pp. 349-364. http://dx.doi.org/10.1016/j.mulfin.2006.08.002

Peng, M \& Jiang, Y 2010, 'Institutions behind family ownership and control in large firms', Journal of Management Studies, vol. 47, no. 2, pp. 253-273. http://dx.doi.org/10.1111/j.1467-6486.2009.00890.x

Raviv, A \& Landskroner, Y 2010, The 2007-2009 'Financial Crisis and Executive Compensation: An Analysis and a Proposal for a Novel Structure', Social Science Research Network.

Saleh, N, Rahman, M \& Hassan, M 2009, 'Ownership Structure And Intellectual Capital Performance In Malaysia', Asian Academy of Management Journal of Accounting and Finance, vol. 5, no. 1, pp. 1 - 29.

Salim, B \& Wan-Hussin, W 2009, 'Remuneration Committee, Ownership Structure and Payfor-Performance: Evidence from Malaysia', Social Science Research Network.

Schulze, WS, Lubatkin, MH, Dino, RN \& Buchholtz, AK 2001, 'Agency relationships in family firms: Theory and evidence'. Organization Science, pp. 99-116. http://dx.doi.org/10.1287/orsc.12.2.99.10114 
AABFJ | Volume 8, no. 3, 2014

Young, M, Peng, M, Ahlstrom, D, Bruton, G \& Jiang, Y 2008, 'Corporate governance in emerging economies: A review of the principal-principal perspective', Journal of Management Studies, vol. 45, no. 1, pp. 196-220.

http://dx.doi.org/10.1111/j.1467-6486.2007.00752.x 